\title{
Governance, democracy and development
}

\author{
Yashar Tarverdi \\ Curtin Business School \\ Curtin University, Australia \\ Shrabani Saha* \\ Lincoln International Business School \\ University of Lincoln, United Kingdom
}

Neil Campbell

Bond Business School

Bond University, Australia

\begin{abstract}
While it is obvious that the level of democracy will affect the quality of governance, we show that an electoral democracy should not be expected to have an improved level of governance when compared with an outright authoritarian regime. We use the term 'electoral democracy' to refer to where relatively free and fair elections are held (where opposition parties stand some chance of winning government) but the institutions of a liberal society (like freedom of the press) are not in place. Given this, we consider what level of democracy is necessary before we can expect it to have a positive effect upon governance. We employ a Principal Component Analysis (PCA) to construct a new governance indicator. Using the data from over one hundred countries and advanced panel data analysis for the period 1996-2012, our results confirm that political freedom and civil rights influence the level of governance, but this effect is found to be nonlinear. Governance is typically higher in dictatorships than in countries that are partially democratized (electoral democracies). However, once past a threshold, democratic practices assist good governance. Furthermore, it is found that democracy substantially strengthens levels of governance only within the top-half of the conditional distribution.
\end{abstract}

Keywords: Democracy, governance, country studies, panel data JEL Classification: K4, H1, O5

\footnotetext{
*Corresponding author: Shrabani Saha, email: ssaha@lincoln.ac.uk
} 


\section{Governance, democracy and development}

\section{Introduction}

While the term 'governance' dates back to the middle ages, its use in the development literature essentially began in the late 1980s (François, 2009, p. 6). The World Bank (1994, p. xiv) cites the World Bank (1989) report on Sub-Sahara African development as an early user of the governance concept in this context. The World Bank (1992, p. 52) gives the following definition of governance for the World Bank's purposes:

“...the manner in which power is exercised in the management of a country's economic and social resources for development.”

Within the academic literature there are differing approaches to the concept of governance. In Frederickson's et al. (2015, p. 242) masterful discussion of this literature, the broadest concept of governance is defined as follows:

“"Governance" is simply a surrogate word for public administration and policy implementation. Thus, governance theory is an intellectual project attempting to unify the various intellectual threads running through a multidisciplinary literature into a framework that covers this broad area of government activity.".

A broad definition fits comfortably with an empirical approach by Kaufmann et al. (1999, p.1) in their work on the Worldwide Governance Indicators (WGI) which define governance as "the traditions and institutions by which authority in a country is exercised". Making use of the WGI, we find it is useful to regard governance as consisting of the following components: political stability and absence of violence/terrorism, control of corruption, effectiveness of government quality, regulatory quality, and rule of law.

By now it is widely recognised that a simple binary distinction between dictatorship and democracy is inappropriate. With Huntington's (1991) third wave of democratisation in the 
late 20th Century, it became clear that it is necessary to recognise the cases where elections are relatively free and fair, but the institutions associated with liberal democracy, such as a free press, are missing. Here we will use the term 'electoral democracy' to refer to this class of regime (Diamond, 1996; Tronquist, 1999). Various alternative terms (Levitsky and Way, 2002, p. 51) include: hybrid regime, semidemocracy, pseudodemocracy, illiberal democracy ${ }^{1}$, semiauthoritarianism, soft authoritarianism, electoral authoritarianism, and competitive authoritarianism. While some of the most thorough work on this subject has been done by Levitsky and Way (2002 and 2010) using the term competitive authoritarianism, we choose to use the term electoral democracy to emphasise that we are meaning a wide variety of regimes that are neither dictatorships nor liberal democracies. That is, at one end of the spectrum there is hegemonic authoritarianism (Morse 2012) where it is possible, but unlikely because of persecution, that opposition parties will win government, and, at the other end of the spectrum is the transitional case where attitudes to due process and the separation of powers strengthen over time and hence there is a potential path being followed towards liberal democracy. Thus, when considering electoral democracy, it is important not to emphatically insist that there is a teleological process that will result in an inevitable shift towards liberal democracy. However, while, there are electoral democracies where there is no sign of a temporal shift to liberal democracy, such as the Russian Federation, over the last four decades the Republic of Korea has provided a good example of a shift from authoritarianism through electoral democracy and on to liberal democracy. In some senses the functioning of liberal democratic institutions is dependent upon personal attitudes (for example: regarding as important freedom of speech, due process, the separation of powers and the rule of law) and some of these attitudes may only evolve with generational change. Consider the following example from Kyu and Salwen (1990). During the electoral democracy period in the Republic of Korea a group of disabled

\footnotetext{
${ }^{1}$ The term 'illiberal democracy' was popularised by the widely-read work of Fareed Zakaria (2004).
} 
veterans in 1989 attacked and injured 20 staff members of a provincial daily newspaper. The veterans were unhappy that the newspaper had reported that there was some impropriety in the way the veterans' village was awarded a contract. A decade before this, these veterans would have been living in an outright military dictatorship where the idea of a civilian newspaper insulting members of the military would have been unthinkable. While the Russian Federation remains an electoral democracy at the more authoritarian end of the spectrum, Hahn and Logvinenko (2008) find evidence that the younger generations have a more favourable attitude to democratic values and institutions than the generations that came of age politically during the Soviet period. How much this will result in reform of Russian institutions over the next few decades is difficult to predict. In many ways we should not be surprised that institutions may take a long time to mature; in Britain, while universal male suffrage was only essentially put in place in the late $19^{\text {th }}$ Century, Britain had by the early $18^{\text {th }}$ Century a more-or-less independent judiciary, a vigorous (although at times scurrilous) free press and established political parties. Thus, here, the institutions associated with liberal democracy had a long time to mature (Klerman and Mahoney 2005).

In this paper we consider democracy as an explanatory factor for governance; our initial curiosity was sparked by the literature on the non-linear relationship between democracy and corruption (Doig, 2000; Montinola and Jackman, 2002; Sung, 2004; Rock, 2009; Saha et al., 2014). While corruption tends to be at its lowest in liberal democracies, there is a tendency for corruption to actually increase with the shift from dictatorship to electoral democracy. Corruption can, of course, have very negative implications for growth, but there are examples such as the Republic of Korea where strong levels of growth have occurred in spite of substantial levels of corruption. By contrast, poor levels of governance, which is a much broader concept than high levels of corruption, is bordering on the concept of a 'soft state', if 
not a 'failed state', and is almost unambiguously associated with, at best, slow levels of growth (Dzhumashev, 2014).

There is a widespread, and unsurprising, consensus that improvements in governance can enhance economic development $^{2}$ (Dzhumashev, 2014; Saha and Gounder, 2013; Brown-Shafii, 2011; Quinn and Dawson, 2011; and Wabuke, 2010). However, translating this into policy terms is problematic. Even where the head of government has a genuine commitment to improving governance, actual improvements in governance may be very limited in the short and medium term. Thus, making development aid conditional on the level of governance has been subject to criticism (Nanda, 2006). Such aid policies can be parodied as 'we will only give you development aid once you become sufficiently developed'. In this paper we find a relationship between democracy and governance, such that a transition from electoral democracy to liberal democracy tends to improve the level of governance (and conversely, staying at the level of electoral democracy is associated with a lack of improvement in governance). The implication of this is that development aid should not be withheld from an electoral democracy with poor levels of governance. Rather, as well as general development aid, assistance should be given to develop the institutions associated with liberal democracy (such as an effective and free press) and targeted directly at improving governance such as training programs for civil servants ${ }^{3}$.

It is important to emphasise that governments have a limited capability to rapidly improve governance using policy measures. Stoker (1998, p. 18) makes the following distinction between government and governance:

\footnotetext{
${ }^{2}$ In the context of development 'governance' is characterised by placing a strong emphasis on institutional performance and thus sits comfortably with the seminal work of North (1990) that focuses on the links between institutions and economic growth.

${ }^{3}$ Using aid to improve governance presents many difficulties, but is clearly important and has been prioritised to a significant degree since the 1990s (Carothers and de Gramont, 2011).
} 
"Governance refers to a set of institutions and actors that are drawn from but also beyond government."

Corrupt, lazy and incompetent civil servants are difficult to rapidly replace or re-educate. Frequently neither of the parties to a corrupt transaction wants to complain ${ }^{4}$. Lazy and incompetent civil servants can hide behind collective responsibility and a lack of resources. The governance literature emphasises the organic and interactive nature of governance (Kooiman and Van Vliet, 1993). For example, a culture of land care and soil conservation can build up over time with the formation of self-help groups of farmers. While government agencies may take initiatives to facilitate the formation of such groups, the conservation groups will only succussed if non-state actors (farmers) are prepared to take the initiative and interact with each other. In the context of an electoral democracy where money-politics is pervasive, such groups might simply be a mechanism for channelling funds to the supporters of the ruling party $^{5}$

Now we turn to explaining why we hypothesise that the transition from a dictatorship to an electoral democracy tends to make governance worse while the evolution of electoral democracy to liberal democracy tends to improve governance. To start with, it is quite apparent why the transition from a dictatorship to an electoral democracy does not tend to improve governance. With a lack of civil and legal rights, citizens lack an effective voice to object to government projects and policies that either pander to certain sectional interests, or, are simply poorly thought through. While a regime in an electoral democracy may have less explicitly coercive powers than a dictatorship, government critics can face violence from non-state actors

\footnotetext{
${ }^{4}$ Of course, it is also frequent for people going about their legitimate business to be 'shaken down' for bribes by corrupt police or other officials. While this causes the victims to be very angry, without an effective investigating and prosecuting institution, they have no one to complain to. Transparency International (2016) regards the police and judiciary in Afghanistan as being dysfunctional and thus corruption can flourish with impunity.

${ }^{5}$ Kang (2002) gives the Korean example of the New Village Movement from the 1970s. He regards it as essentially a mechanism for transferring wealth to government supporters. For a discussion of 'clientelist' policies in young democracies see Keefer (2007).
} 
who are in some way aligned with the regime (Koonings and Kruijit, 2004, p. 44). Also, where the media is controlled by the regime, criticisms of government policy will typically lack effectiveness (Freedom House 2015).

A transition from a dictatorship to an electoral democracy typically involves institutions, such as prosecuting authorities, being traumatised (because of leadership changes and/or underresourcing) thus causing a deterioration in governance. In the chaotic and uncertain environment associated with electoral democracies officials and politicians might accumulate funds, from bribes and graft, as quickly as possible so they can escape to a foreign country if an unfriendly regime comes to power. Also, once a dictatorship is no longer in power officials may feel free to pursue their own agenda ${ }^{6}$.

With the establishment of liberal democracy, governance levels can be expected to improve because with a free media, an independent judiciary and genuine political competition, bad governance can be challenged and replaced by better governance. For instance, there are a myriad of examples of governments which have lost elections because of credible allegations of cronyism or corruption ${ }^{7}$. Also, liberal democracy allows civil society groups to develop and these groups frequently contribute to improved governance. For instance, charitable organisations provide debt counselling to low-income individuals while government institutions may not provide such services because of fiscal pressure. It is also important to note that, as governance improves this will enhance the quality of democracy ${ }^{8}$. For example, a well-functioning bureaucracy, charged with operating the electoral system, will have the

\footnotetext{
${ }^{6}$ Shleifer and Vishny (1993) contrast the 'centralised corruption' associated with a powerful dictator with the 'decentralised corruption' associated with a chaotic electoral democracy where each corrupt official acts to maximise his/her revenue from bribes.

${ }^{7}$ Jacobson (2012) lists a number of US state governors who have lost elections following allegations of abuse-ofpublic-office.

${ }^{8}$ The authors want to thank an anonymous referee for pointing out this recursive relationship between governance and democracy.
} 
initiative and independence to adjust electoral boundaries so that the boundaries do not favour one political party over another.

The introduction of the six-dimensioned Worldwide Governance Indicators (WGI) by Kaufmann et al. (1999) represented a major breakthrough in empirical research relating to governance. In spite of that, researchers have encountered difficulties in using WGIs for the dependent variable and various studies in economics and political science have used the WGI indicators either by aggregating or converting all the indicators or by considering the individual or composite components as proxies for governance (Langbein and Knack, 2010). To surmount the problem of measurement, we construct a new governance indicator by employing Principal Component Analysis (PCA), a powerful statistical technique to determine the important component(s) among many dimensions ${ }^{9}$. With a newly constructed governance indicator we examine whether democracy improves governance using over one hundred countries and employing advanced panel data analysis for the period 1996-2012.

While our work uses a quite different methodology to Pritchett and Kaufmann (1998) their results are consistent with ours. They find that simply establishing electoral democracy does not facilitate improved governance; however, they find that improving civil liberties is associated with better governance. That is, civil liberties (typically associated with maturing liberal democracy) allow citizens to voice their opinions on government policies and practices and this leads to an improvement in governance. Stockemer (2009) also gets results that essentially appear to be consistent with ours. He chooses to use African and Latin American data and finds a positive relationship between democracy and governance. This can be explained in terms of democracies that are closer to full liberal democracy having higher levels of governance. Stockemer (2014) goes on to consider an analysis where countries are divided into sub-samples based on development levels. Here, he simply classifies countries as either

\footnotetext{
${ }^{9}$ PCA has been widely used in the literature for dimensionality reduction.
} 
being democratic or authoritarian. His results support the contention that democratic states have better governance levels than authoritarian states.

Our paper explores what level of democracy is crucial for good governance. It differs from earlier literature in several ways: first, a governance indicator is constructed by employing Principal Component Analysis (PCA), a useful technique for dimensionality reduction. Second, we explicitly explore the non-linear effect of democratization on governance allowing us to consider a much broader perspective. There is no cross-country evidence in the existing literature that captures the nonlinear effects on the democracy-governance relationship. Third, the consistency of our results across various levels of governance is tested using quantile regression. Fourth, we examine the link between democracy and governance across different regime types - 'free' and 'not free' countries. Fifth, along with our aggregate measure of democracy, we examine the individual dimensions to identify the crucial aspect of democracy that contributes towards good governance. Sixth, we also consider spiritual beliefs (e.g. religion) and gender parity which have not been studied before. Finally, our work contributes to the literature by improving the methodology and model selection. The non-linear effects are tested by utilizing the most advanced semi-parametric panel data techniques. It also extends the geographical and economical grouping and covers a relatively large period, from 19962012. We turn next to a discussion of the model used, the data employed, and the estimation techniques.

\section{Data, Models and Methodology}

The dependent variable in this study is governance. Like corruption, there is no universally accepted definition of governance. It is an elusive concept; there is no unanimity about what comprises good governance (Andrews, 2010; Gisselquist 2012; Mkandawire, 2007). Thus, different researchers emphasise different aspects of the problem depending on the subject under 
examination. Fortunately, with the advent of the Worldwide Governance Indicators (WGI), developed by Kaufmann et al. (1999), empirical researchers have been placed in a strong position to explore the causes of good governance and we use these indicators as the source of our dependent variable. Kaufmann et al. (1999, p.1) construct the six dimensions of governance which are: i) Voice and Accountability; ii) Political Stability and Absence of Violence/Terrorism; iii) Government Effectiveness; iv) Regulatory Quality; v) Rule of Law; and vi) Control of Corruption. There are varying aspects of the six indicators i.e. each individual indicator measures different things. While the voice and accountability indicator has been constructed to demonstrate the democratic process of governments, other indicators capture the various governance processes such as control of corruption, effectiveness of government quality, rule of law etc. For the purpose of our study, the voice and accountability component is excluded because it represents democratic aspects of governance. Therefore, we use the five remaining WGI indicators for constructing a governance proxy by employing principal components analysis (PCA). ${ }^{10}$ The results of the PCA are shown in Table 1.

\section{[TABLE 1 ABOUT HERE]}

Note that the eigenvalue of the first component is much higher than the other components. ${ }^{11}$ Also, the first component successfully explains almost $89 \%$ of variation in the dataset ${ }^{12}$. Therefore, the score of each observation based on this component can be used as the reduced

\footnotetext{
${ }^{10}$ Principal Component Analysis (PCA) finds the combination of the variables which explains the phenomena. The number of principal components is less than, or equal to, the number of original variables. PCA has been widely used in the literature for dimensionality reduction.

${ }^{11}$ An eigenvalue gives the components in order of significance. If the eigenvalues are small, then the components can be ignored without losing much information.

${ }^{12}$ Another way to determine the number of new variable(s) is to look at the cumulative proportion of variance. This means the extent to which the information that the original data have can be described by the combination of the new variables. For instance, the component 1 can describe $87 \%$ of the information the original data have. Generally, $80 \%$ is considered as the percentage which describes the data well. So, in this case, we can take component 1 and ignore others.
} 
dimension of governance aspects (i.e. proxy for governance). In addition, the scree plot presented in Figure 1 confirms the usage of first component score as an indicator for governance. $^{13}$

\section{[FIGURE 1 ABOUT HERE]}

Each dimension of the original WGI has a normal distribution with zero mean and unit variance and ranges between -2.5 to 2.5 . However, the new constructed index for governance ranges from -6 to 5 and a higher score indicates a better governance. ${ }^{14}$

The main independent variable in this study, democracy, also suffers from the problem of measurement (Coppedge, 2002; Munck and Verkuilen, 2002 for details). For the purpose of this study, the Polity IV institutionalized democracy index is used as the principal measure of democracy. The index is based on the competitiveness of political participation, the openness and competitiveness of executive recruitment and constraints on chief executives. ${ }^{15}$ It measures the degree of democracy and autocracy. The most widely used Polity IV index is an additive eleven-point scale (0-10) and a higher value indicates a higher level of democracy.

As an umbrella concept democracy combines multiple components into one index. However, Jackman (1985) suggests that it is imperative to focus on the individual components as well. In order to examine the effectiveness of individual dimensions of democracy, the 'democracy barometer' index developed by the University of Zurich (UZH) and the Social Science Research Centre Berlin (WZB) is used for more in-depth analysis. ${ }^{16}$ The democracy

\footnotetext{
${ }^{13}$ The scree plot is a useful visual aid for determining an appropriate number of principal components. The scree plot graphs the eigenvalue against the component number. An "elbow" in the scree plot determines the appropriate number of components. The component number is taken to be the point at which the remaining eigenvalues are relatively small and all about the same size.

14 The constructed index is used without any normalization as it is believed that normalizing the constructed variable would change the distribution across countries.

${ }^{15}$ See http://www.systemicpeace.org/polity/polity4.htm for details.

${ }^{16}$ See http://www.democracybarometer.org/about_en.html for details. The advantage of the democracy barometer is that it uses, whenever possible, hard and aggregated survey data.
} 
barometer takes into account both a country's institutional setting (rules in law) as well as the effectiveness of those institutions in practice (rules in use). The overall quality of democracy in a democratic country is based on three principal components, namely, freedom, control and equality and each component is constructed on multiple criteria. ${ }^{17}$ Each index ranges from 0 to 100 and a higher value indicates a better democratic performance.

An economic freedom index (EF), sourced from the Heritage Foundation, is included as an institutional control variable that measures the level of regulation on economic activities in a country. Other socio-economic variables incorporated as the control variables are per capita real gross domestic product (RGDP), population (POP), Gini index (GINI) of inequality and secondary level of education (SED) and these variables are obtained from the World Bank World Development indicators. For sensitivity analysis we include federal states and Protestant, Muslim and Catholic tradition variables which are based on the Quality of Government (QOG) Standard Dataset. ${ }^{18}$ Additional controls such as natural resource abundance, women in parliament and ethnolinguistic fractionalization variables are obtained from the World Development Indicators dataset. Summary statistics and the data sources are provided in Appendixes 1 and 2, respectively.

\subsection{Models}

This paper examines the non-linear democracy - governance relationship using recent data covering over 100 countries during 1996-2012. We begin the analysis by focusing on a basic linear regression model to measure the impact of democracy on governance which is specified as:

\footnotetext{
${ }^{17}$ Each component consists of at least one subcomponent that measures rules-in-law and rules-in-use.

${ }^{18} \mathrm{See} \mathrm{http://www.gaportal.org/global-indicators/quality-of-government-datasets-qog-standard-dataset} \mathrm{for} \mathrm{details.}$
} 
$G G_{i, t}=\beta_{0}+\beta_{1} D E M O_{i, t}+\beta_{2} \log R G D P_{i, t}+\beta_{3} \log P O P_{i, t}+\beta_{4} S E D_{i, t}+\beta_{5} E F_{i, t}+\beta_{6} F E D E R A L_{i, t}$ $+\beta_{7} N R A_{i, t}+\beta_{8}$ RELIGION $_{i, t}+\beta_{9}$ WOMENP $_{i, t}+\beta_{10}$ GINI $_{i, t}+\varepsilon_{i, t}$

where GG is governance indices; DEMO is democracy indices; RGDP is real gross domestic product per capita; POP is population; SED is secondary enrolment; EF is economic freedom; FEDERAL is federal states; NRA is natural resource abundance; RELIGION is percentage of various religions; WOMENP is proportion of women in national parliament; GINI is incomeinequality index; and $\varepsilon$ is error term for country $i$ in time $t$.

The sign and significance of $\beta_{1}$ is of interest. In particular, if $\beta_{1}$ turns out to be positive, it reflects that a greater democracy improves governance practices. Both $\beta_{2}$ and $\beta_{4}$ coefficients tend to be associated with increases in the level of economic development which should foster good governance by facilitating sophisticated bureaucracies, better infrastructure and decision making (Stockemer, 2009). The population coefficient $\beta_{3}$, is expected to be negative, as countries with large population size should be more difficult for the government to distribute resources equally, execute rules and laws and maintain transparency (Stockermer, 2009, 2014). The recent corruption literature identifies economic competition as an important determinant of governance, in particular, Ades and Di Tella (1999), Saha et al., (2009) and Treisman (2000) argue that economic competition tends to reduce corruption by lowering the rewards from engaging in corruption due to the greater competition in the product markets. Therefore, the coefficient $\beta_{5}$ is expected to be positive. Also, based on the fact that federalism can create competition among regions and increase efficiency and transparency, we expect $\beta_{6}$ to be positive. At the same time, natural resource abundance may lead to poor governance and increased corruption due to the greater potential gain to officials who have authority to set policy and allocate rights to exploit such resources (Ades and Di Tella, 1999; Treisman, 2000). Moreover, natural resource abundance may reduce government's dependence on its citizenry 
for tax revenue and thereby decreases citizens' demand for accountability and transparency from governments (Al-Marhubi, 2004).

The coefficients $\beta_{8}$ and $\beta_{9}$ provide interesting insights about the religious and gender sensitivity. Landes (1998) and Lipset (1994) emphasise the role of religious affiliation in determining governance. Religious traditions provide the richest source of values and are important because they condition cultural attitudes toward social hierarchy and authority. Moreover, religious traditions differ in the degree of separation between political and religious beliefs and drawing the line between the spiritual and temporal. The separation of the religious from the political is believed to increase a country's propensity to experience democracy. Thus, a common view in the literature is that Protestantism is positively related with governance relative to other religious affiliations because it is more egalitarian, less hierarchical and more individualistic. There is growing public support for women's increased political participation, since they are perceived to be more trustworthy and competent than men (McGrew et al., 2004). Finally, it is a common belief that the more unequal society is, the poorer the governance is. Hence, the expected sign of $\beta_{10}$ is negative.

The second step examines the nonlinear democracy - governance nexus in a quadratic form:

$G G_{i, t}=\beta_{0}+\beta_{1} D E M O_{i, t}+\beta_{2} D E M O_{i, t}^{2}+\beta_{3} \log R G D P_{i, t}+\beta_{4} \log P O P_{i, t}+\beta_{5} S E D_{i, t}+\beta_{6} E F_{i, t}+$ $\beta_{7}$ FEDERAL $_{i, t}+\beta_{8}$ NRA $_{i, t}+\beta_{9}$ RELIGION $_{i, t}+\beta_{10}$ WOMENP $_{i, t}+\beta_{11}$ GINI $_{i, t}+\eta_{i, t}$

where $\eta$ is the error term. The non-linear democracy-governance association is reflected by the coefficients $\beta_{1}$ and $\beta_{2}$, where the expected sign for $\beta_{1}$ is negative and $\beta_{2}$ as positive. These expected signs of $\beta_{1}$ and $\beta_{2}$ represent a U-shape relationship between democracy and governance. It reflects that at a certain value of democracy the marginal effect of democratization on governance is 0 . Therefore, before this threshold level of democracy the 
effect on governance is negative which becomes positive after a certain threshold level of democracy. Hence, at the early stages of democratization an increase in democracy reduces the governance level until it reaches a minimum level, i.e. the threshold point, and thereafter with improved mature democracy it has an enhancing effect on governance. In other words, the quadratic equation hypothesises is that as democratization progresses governance level tends to be weak first and then becomes stronger as the institutions and conventions associated with liberal democracy become stronger.

The next step includes examining individual dimensions of democracy, namely freedom (Free), control (CNL) and equality (EQL) to measure the quality of democracy and its impact on governance. Finally, we test the existence of non-linearity across different levels of our dependant variable, that is, governance using quantile regression.

\subsection{Methodology}

In order to estimate the proposed hypothesis, first, a panel least squares (PLS) model is used based on the available data, then to address some of the potential econometrics problems in least square estimation, we estimate the main equations using two-stage-least-square and advanced Dynamic-Panel-Data-technique called System-GMM.

While, estimating the main equation using PLS, we test the hypothesis of fixed effects (FE) against random effects (RE) using Hausman test. Therefore, to control for both time and country level specifications, and considering the possible non-linearity of the relationship, a two-way FE model is structured as follows:

$$
G G_{i, t}=\alpha_{0}+\alpha_{1} D E M O_{i, t}+\alpha_{2} D E M O_{i, t}^{2}+\beta_{k} X_{i, t}+u_{i}+e_{t}+\varepsilon_{i, t}
$$

where, $X_{i, t}$ is the vector of explanatory variables that varies over time and country; $\beta_{k}$ is the vector of coefficients for $X_{i, t . ;} u_{i}$ is individual-level effect; $e_{t}$ is the time period effect and $\varepsilon_{i, t}$ is the disturbance term. As it is mentioned above, the existence of RE in the model is also tested. 
While the Hausman test reveals that the null hypothesis of RE can be rejected with a high level of significance, the extended Wald test for group wise heteroskedasticity in FE regression models shows that the models suffer from serious heteroskedasticy. However, the results are presented after controlling for both heteroskedasticity and serial correlation with robust standard errors. ${ }^{19}$

\subsection{Non-linearity between governance and democracy}

The result of estimating the significant parameters in the model such as in equation (3), suggests that there is a non-linear quadric linkage between democracy and governance. However, the true non-linear relationship could be in a different form to that of a quadric one. We address this issue, using semi-parametric panel data models, to test the hypothesis of existence of non-linearity between governance and democracy and if the function relating them is unknown. However, the relationship between control variables and governance is assumed to be linear. In general form, the model in equation (3) changes to the following equation.

$$
G G_{i, t}=\alpha_{0}+f\left(D E M O_{i, t}\right)+\beta_{k} X_{i, t}+\varepsilon_{i, t}
$$

In spite of the difficulty in finding the exact functional relationship between democracy and governance, the methodology of estimating the partial-linear-panel-data models with FE introduced by Baltagi and $\mathrm{Li}$ (2002) can find the marginal effects of democracy on governance. This methodology is implemented as an independent package for Stata-software by Verardi and Libois (2012) and using the package we estimate the above equation and find the estimated value of governance for different values of democracy in partial-linear form.

\subsection{Endogeneity between democracy and governance}

\footnotetext{
${ }^{19}$ Autocorrelation test shows that there is also a problem of serial correlation in the dataset.
} 
The results of least square panel data with FE provide an important insight into the linkage we are interested in. However, they can render biased estimates due to the potential problem of endogeneity between several of our variables such as governance and democracy, and, governance and income-inequality. Additionally, there could be an endogeneity between GDP per capita and governance and which can cause the error terms to be correlated with dependent variables. ${ }^{20}$ Although we have considered a vector of control variables to reduce the problem of endogeneity, there could be yet some factors that cause changes on both democracy and governance.

To address the problem of endogeneity we re-estimate equation (2) by employing both TwoStage-Least-Square (TSLS) and System-GMM-Dynamic-Panel (SGDP). One of the key factors in estimating TSLS is to find an appropriate and efficient Instrument Variable/s (IV) that has a significant relationship with explanatory variables without having any significant effect on the dependent variable. Following Mobarak (2005), Rock (2009) and Saha et al. (2014) we use the percentage of various religions in countries as instrument variables. However, in the regression with the squared term of the endogenous variable, considering the same IVs for both level and squared variables may yield an error known as "Forbidden Regression" (Wooldridge, 2010). Therefore, following Wooldridge, we use the predicted value of democracy square in the first equation as IV for the non-linear regressions.

For the robustness check, we estimate the most advanced SGDP estimators introduced by Arellano and Bond (1991) and later developed by Blundell and Bond (2000) and Bond (2002) to address the problem of endogeneity. ${ }^{21}$ In SGDP, rather than traditional application of regular instrumental variables, lagged variables are used as instruments for their level or differenced.

\footnotetext{
${ }^{20}$ Democracy and income-inequality are endogenously determined in the sense that they are both correlated with exogenous shocks that affect the level of governance.

${ }^{21}$ Also, System GMM is used to identify the causal effect of democracy on governance as there may be some time-invariant omitted variables influencing political variables, which cannot be controlled for by FE.
} 
In SGDP there are two main equations, the first equation is the equation in the levels and the second one is the differenced equation. Lagged differences of variables are used as instruments in the level equation and lagged variables are used for instruments in the first difference equation.

After establishing our model and finding the coefficients of interest, the threshold level of democracy's contribution to governance is estimated. Furthermore, the current literature lacks an answer as to whether greater democracy consistently improves governance among the-mostand-the-least-effective governing nations. The effects of democracy in enhancing governance at different stages is examined using quantile regression to check the stability of the results in different groups of countries based on the level of governance.

\section{Results}

This section analyses the empirical results of the role of democracy in affecting governance. To begin with, the scatter plots of democracy and governance indicators of the countries examined in this study are shown in Figure 2. It is apparent from the figure that the direction of the relationship is not straightforward, and, the possibility of a non-linear relationship may exist between democracy and governance. In other words, democratization does not necessarily transform weak-governance into strong-governance. Hence, this section analyses the empirical results of a rigorous study of the impact of democracy on governance, incorporating control variables using PLS, FE, TSLS and SGDP.

\section{[FIGURE 2 ABOUT HERE]}

We begin with a simple model that casts governance as a function of democracy, with economic and social control variables using PLS (Table 2) estimates. The results find no 
significant evidence that higher levels of democracy enhance governance. The democracy coefficient is positive, but insignificant (columns (1)-(2)).

\section{[TABLE 2 ABOUT HERE]}

The scatter plot in Figure 2 illustrates the possibility of a non-linear nexus between governance and democracy. The next step evaluates the possibility more systematically, by reestimating the models with a second-degree polynomial function and the columns (3)-(4) (Table 2) display the set of estimates. The PLS estimates confirm the existence of a non-linear governance-democracy association and the results are significant at all specifications. The nonlinear hypothesis implies that the quality of governance drops initially, but then expands in the course of a country's democratic consolidation. The significant DEMO coefficient value of 0.424 for the linear democracy term is negative and the squared term is positive 0.0442 (column (3)) suggesting that governance effectiveness decreases at the transitional stage of democratization and increases as nations achieve mature levels of democracy. The estimated second-degree polynomial of $\mathrm{DEMO}^{2}$ indicates that a U-shape function better fits the data than the linear one. In addition, inclusion of a quadratic term increases the explanatory power $\left(\mathrm{R}^{2}\right.$ increases in all specifications) suggesting that a quadratic model is more appropriate.

Based on the findings of a U-shape governance relationship, we next estimate the threshold level of democracy at which the governance level changes its direction, i.e. the turning point based on the partial effect of a change in the democracy level:

$\frac{\partial G G}{\partial D E M O}=-0.424+2 \times 0.0442 \times D E M O=-0.424+0.0884 \times D E M O$

Equation (5) shows that when the level of democracy is allowed to vary in our sample, democracy is not governance enhancing at all levels. The estimated turning point value at 
which governance quality starts improving is approximately 4.79 . In the case of China, a country in the sample with the least possible democracy with an average democracy index $(\mathrm{DEMO}=0)$ during 1996-2010, democracy weakens the governance quality. When DEMO reaches 4.8 (the average for Guinea-Bissau during 1996-2010), democracy has no effect on governance at the margin. Beyond this level, democracy actually enhances governance. In the case of Australia, with the highest level of democracy with an average democracy index $(\mathrm{DEMO}=10)$ during 1996-2010, democracy leads to improved governance. Overall, any value below the threshold level, democracy is not effective for improving governance, however, once past a threshold, democratic practices assist governance.

Table 3, column (5) presents two-way FE estimates with a non-linear democracygovernance relationship with robust standard errors. ${ }^{22}$ Fixed effects results confirm the nonlinear effect of democracy on governance.

\section{[TABLE 3 ABOUT HERE]}

On the other hand, control variables reveal mostly the expected signs. The level of economic development measured by log RGDP illustrates a positive and significant impact on governance suggesting that higher levels of GDP are associated with higher levels of governance. This pattern conforms well with the expectations that higher public-sector wages usually decrease the incentives for corruption and enhance governance. Another economic variable related to economic development (SED) shows a positive and significant impact on governance, as expected. The negative population and Gini coefficients indicate that a large population size and greater income disparity reduce governance efficiency. At the same time,

\footnotetext{
${ }^{22}$ The results show that there are significant effects of time in our model and an efficient model should control for time effects. The results of the time dummies are not reported here.
} 
a higher economic freedom provides better governance by limiting rent-seeking activities of public officials.

With respect to the other explanatory variables, the results show that natural resource abundance negatively influences the quality of governance which is consistent with Ades and Di Tella (1999). However, protestant affiliation does seem to be important for better quality of governance than other faiths. Federal states create the opportunities for improved governance as suggested by Treisman (2000). Finally, the estimates imply that a larger female participation rate in politics is associated with good quality of governance. This pattern is noteworthy and consistent with Cammisa and Reingold (2004), which argues that women view government as a tool to help serve under-represented or minority groups more than men do. Interestingly, the exclusion of the Gini coefficient tends to increase the statistical significance of the other variables. In particular, women's participation and federal states which become significant once the Gini coefficient is discounted for (columns (2) and (4), Table 2). Religion variables are replaced with ethnolinguistic fractionalization and the results are interesting; strikingly, inclusion of ethnolinguistic fractionalisation is associated with significantly better quality of governance for both the specification with and without the Gini coefficient. ${ }^{23}$ The result is consistent with Charron and Lapuente (2011). The inclusion of economic, social and institutional factors explains around $80-89 \%$ of the cross-section variations in governance.

\subsection{Non-linearity in semi-parametric settings}

The non-linear governance-democracy relationship presented in Tables (2)-(3) assumes that the non-linearity follows a quadric pattern. However, using semi-parametric regression in panel data, we relax the quadric functional assumption and estimate the coefficients.

${ }^{23}$ The results are not reported here, will be available from authors upon request. 
Figure (3) illustrates the marginal effects of democracy on governance with the confidence intervals. The results confirm the existence of a non-linear linkage between democracy and governance. It can be seen, that, at an initial stage an increase in institutionalized democracy decreases the level of governance slightly then it starts its increasing trend. The panel data semi-parametric regression results confirm our previous findings regarding the non-linearity between democracy and governance.

\section{[FIGURE 3 ABOUT HERE]}

\subsection{Addressing endogeneity: system-GMM / TSLS results}

The system-GMM results (Table 3) confirm the existence of a non-linear relationship. In other words, the linear and squared coefficients in column (6), suggest that an increase in the level of democracy decreases the governance quality in general, however, before a specific level of democracy it has a decreasing trend and then after a point of zero marginal effect it starts its increasing trend. TSLS results for the robustness check are consistent with systemGMM results. ${ }^{24}$ Similar to previous sections, we find that GDP per capita is one of the important factors for governance and an increase in per capita income brings out better governance. Our findings regarding the economic freedom index is consistent with the literature suggesting that an increase in the level of economic freedom enhances governance. In addition, the negative significant effect of the Gini index on governance implies that poorer countries have lower governance after controlling for income per capita. The results also suggest that the percentage of women in parliament is another deterministic factor for governance.$^{25}$

\footnotetext{
${ }^{24}$ The results are not reported here, they will be available from the authors upon request.

25 The results are not reported here, they will be available from the authors upon request.
} 
Also, to note that the probability of the hypothesis of autocorrelation of second order, along with probability of the Hansen test, confirms the stability of our regressions in system-GMMdynamic-panel.

\subsection{Democracy and governance relationship in 'free' and 'not free' countries}

We re-estimate equation (2) based on 'free' and 'not-free' countries during 1996-2012, the results are not reported here. ${ }^{26}$ The results for free countries indicate the existence of a positive governance-enhancing level of democracy with significant democracy and democracy squared coefficients. On the other hand, the estimation results do not allow us to establish any significant correlation between democracy and governance for the subsample of not-free countries.

\subsection{Various democracy indicators and governance relationships}

To explore the non-linear relationship further and to acquire the possible dimension of democracy that has a significant effect on the quality of governance, we re-estimate the base equation (1) with various individual democracy indicators. The two-way FE results for all three individual democracy measures; freedom, control and equality are presented in Table 4 . The computed Freedom coefficient (column (7)) is positive, but weakly significant, suggesting that there is no strong evidence to believe that the freedom component of democracy enhances the quality of governance. ${ }^{27}$ The influence of other individual components of democracy, i.e. Control and Equality (columns (8)-(9)) coefficients are positive, however, the greater magnitude of the Equality coefficient (column (9)) indicates that a one-standard deviation increase in the equality value enhances the quality of governance by 0.0185 points, and

\footnotetext{
${ }^{26}$ The results will be available upon request.

27 The freedom component of democracy comprises individual liberties, rule of law and public sphere liberties. Please see http://www.gaportal.org/global-indicators/quality-of-government-datasets-qog-standard-dataset .
} 
approximately $0.6187 \%$ of a standard deviation in the governance index. In other words, a highly significant Equality coefficient demonstrates a greater ability in enhancing governance than the other two individual measures of democracy. It is important to note here that the equality component of democracy represents democratic transparency, participation and representation. Column (10) confirms that equality produces much stronger effects in enhancing the governance effectiveness. Moreover, it indicates the relevance of transparency as an additional mechanism that countries can utilize to improve the quality of governance. Hence an advanced level of democracy generates greater transparency and greater representation that can improve governance quality effectively.

\section{[TABLE 4 ABOUT HERE]}

\subsection{Quantile regression results}

The final step examines whether greater democracy consistently enhances governance effectiveness among the most and the least quality of governance. We re-estimate the base model using quantile regression FE in panel data in three different quantiles, the $25^{\text {th }}, 50^{\text {th }}$ (median), and $75^{\text {th }}$. We choose quantile regression for two basic reasons. Firstly, quantile regression relaxes the assumption on parametric distribution of error terms and therefore it can be included as one of the non-parametric methods and if our results stand, we can argue that our conclusion is free of assumptions on the distribution of error terms. Secondly, quantile regression is more robust with the existence of outliers in the dataset.

The quantile regressions results presented in Table 5 support our findings in PLS, two-way FE, TSLS and SGDP regressions. The results reveal that the effect of democracy is in nonlinear quadratic form; only a level of democracy beyond a threshold can enhance governance. Furthermore, democracy substantially augments governance quality at a higher quantile (over 
the $75^{\text {th }}$ ) (among the most efficient governance) where the turning point of democracy is reached much faster (approximately at level 3). This finding confirms our hypothesis that democracy is not consistently statistically significant across various quantiles and it calls into question the notion that the transformation to democracy from autocracy uniformly stimulates governance.

\section{[TABLE 5 ABOUT HERE]}

\section{Conclusion}

With the wave of new democracies emerging in the late $20^{\text {th }}$ Century ${ }^{28}$ there has been renewed interest in the relationship been democracy and economic performance. There are good reasons to believe that with liberal democracy (with its transparency, effective legal system and political competition) that there will be good governance that will translate into improved social cohesion and economic performance. However, typically these new democracies are/were electoral democracies and frequently such regimes are characterized by corrupt and incompetent administration resulting in economic problems and social tensions. This paper confirms the above contentions using a newly constructed governance indicator by employing PCA allowing us to engage in a systematic empirical analysis controlling for the endogeneity issue that specifies the effects of democracy on governance for the periods 19962012 for over one hundred countries (with various economic, social and institutional controls to evaluate the stability of our estimates).

The most important implication of this study is that democracy matters for governance; however, there is a threshold level in this relationship. Governance quality is typically weaker in countries with intermediate levels of political freedom than in their less democratic counterparts, but once past the threshold level, greater political competition is associated with

\footnotetext{
${ }^{28}$ Huntington (1991) refers to this as the third wave of democratization.
} 
considerably stronger governance. In other words, governance effectiveness is likely to be slightly higher in autocracies than in countries that have newly-born democracies ${ }^{29}$. However, with more consolidated democratization, countries experience a much higher quality of governance. Furthermore, the findings on the relationship are robust across different levels of governance; this implies that there is a non-linearity in the relationship between governance and democracy across different level of governance. This pattern is consistent with various specifications, estimation techniques and alternative indicators of democracy.

Our results suggest that where political freedoms, representation and democratic transparency, are limited, the quality of governance is likely to be reduced even with relatively free and fair elections (electoral democracy). The results provide an insight into the weak levels of governance observed in a country like India. A good deal of the blame for the weak governance can be placed on ineffectual institutions and lack of transparency in the democratic information process, even though India exhibits fair electoral competition, checks and balances and a high degree of federalism. On the other hand, mature liberal democracies like Australia and Denmark experience the highest quality of governance.

The results for control variables suggest that the effectiveness of governance increases with increasing economic development, as reflected by RGDP per capita, and education. Large population, unequal distribution of income and natural resource abundance reduce governance quality. Furthermore, higher economic and state freedom enhances governance. Finally, religion and gender sensitivity analysis show that a protestant tradition and women's participation in politics help to improve the quality of governance. The results remain robust under various estimations and for alternative measures of democracy. The policy implications are that there is a need to establish effective and efficient democratic institutions in order to

\footnotetext{
${ }^{29}$ Of course, electoral democracy is not only confined to newly born democracies. Think of the Russian Federation and the Philippines.
} 
establish good quality governance so as to control corruption and generally allow the state to achieve its social and economic objectives. Moreover, effective institutions require a high level of transparency, participation and representation which in turn strengthen the quality of governance. Hence, transition countries can overcome the problem of weak governance once the democratic consolidation has, over time, been achieved. 


\section{REFERENCES}

Ades, A. and Di Tella, R. 1999. Rents, Competition, and Corruption. American Economic Review, 89, 982-993.

Al-Marhubi, F. 2004. The Determinants of Governance: A Cross-Country Analysis. Contemporary Economic Policy, 22, 394-406.

Andrews, M. 2010. Good Government Means Different Things in Different Countries. Governance, 23, 7-35.

Arellano, M. and Bond, S. (1991). Some Tests of Specification for Panel Data: Monte Carlo Evidence and an Application to Employment Equations. The Review of Economic Studies, $58,277-97$.

Baltagi, B. H. and Li, Q. (2002). On Instrumental Variable Estimation of Semiparametric Dynamic Panel Data Models. Economics Letter, 76, 1-9.

Blundell, R. and Bond, S. 2000. GMM Estimation with Persistent Panel Data: An Application to Production Functions. Econometric Reviews, 19, 321-340.

Bond, S. R. 2002. Dynamic Panel Data Models: A Guide to Micro Data Methods and Practice. The Institute for Fiscal studies Department of Economics, UCL CEMMAP working paper CWP09/02.

Brown-Shafii, S. 2011. Promoting Good Governance, Development and Accountability: Implementation and the WTO. Basingstoke: Palgrave Macmillan Ltd.

Cammisa, A. and Reingold, B. 2004. Women in State Legislatures and State Legislative Research: Beyond Sameness and Difference. State Politics and Policy Quarterly, 4, 181210.

Carothers, T. and De Gramont, D. 2011. Aiding Governance in Developing Countries: Progress Amid Uncertainties. Carnegie Papers: Democracy and Rule of Law, November, Carnegie Endowment for International Peace. 
Charron, N. and Lapuente, V. 2010. Does democracy produce quality of government? European Journal of Political Research, 49, 443-470.

Charron, N. and Lapuente, V. 2011. Which dictators produce quality of government? Studies in Comparative International Development, 46, 397-423.

Coppedge, M. 2002. Democracy and Dimensions: Comments on Munck and Verkuilen. Comparative Political Studies, 35, 35-39.

Diamond, L. 1996. Is the Third Wave Over? Journal of Democracy, 7, 20-37.

Doig, A. 2000. In the State We Trust? Democratization, Corruption and Development. In A. Doig and R. Theobald (eds), Corruption and Democratization. London: Frank Cass.

Dzhumashev, R. 2014. Corruption and growth: The role of governance, public spending, and economic development. Economic Modelling, 37, 202-215.

François, R. 2009. Why Should World Governance Be Evaluated, and for What Purpose? World Governance Index, Forum for a new World Governance, Proposal Papers Series.

Frederickson, H. G., Smith, K. B., Larimer, C. W., \& Licari, M. 2015. The public administration theory primer. Boulder, CO: Westview Press.

Freedom House 2015. Freedom of the Press 2015: Russia. Retrieved from: https://freedomhouse.org/report/freedom-press/2015/russia .

Gisselquist, R. M. 2012. Good governance as a concept, and why this matters for development policy. WIDER Working Paper No. 2012/30.

Hahn, J. W. and Logvinenko, I. 2008. Generational Differences in Russian Attitudes towards Democracy and the Economy. Europe-Asia Studies, 60, 1345-1369.

Huntington, S. P. (1991). The Third Wave: Democratization in the Late Twentieth Century. Norman: University of Oklahoma Press.

Jackman, R. 1985. Cross-National Statistical Research and the Study of Comparative Politics. American Journal of Political Science, 29, 161-182. 
Jacobson, L. 2012. What It Takes for a Governor to Lose Reelection. Governing the States and Localities, January 5. Retrieved from: http://www.governing.com/blogs/politics/whatit-takes-for-a-governor-to-lose-reelection.html .

Kang, D. C., 2002. Bad Loans to Good Friends: Money Politics and the Developmental State in South Korea. International Organization, 56, 177-207.

Kaufman, D., Kraay, A. and Zoido-Lobaton, P. (1999). Governance Matters. World Bank Policy Research Working Paper No. 2196.

Keefer, P. 2007. Clientelism, credibility, and the policy choices of young democracies. American Journal of Political Science, 51, 804-821.

Klerman, D. and Mahoney, P. 2005. The Value of Judicial Independence: Evidence from Eighteenth Century England. American Law and Economics Review, 7, 1-27.

Kooiman, J. and Van Vliet, M. 1993. Governance and Public Management. In K. Eliassen and J. Kooiman (eds), Managing Public Organisations ( $2^{\text {nd }}$ edn), London: Sage.

Koonings, K. and Kruijit, D. 2004. Armed Actors: Organised Violence and State Failure in Latin America. London: Zed Books.

Kyu, H.Y. and Salwen M.B., 1990. A Free Press in South Korea: Temporary Phenomenon or Permanent Fixture? Asia Survey, 30, 312-325.

Landes, D. 1998. The Wealth and Poverty of Nations. New York: Norton.

Langbein, L. and Knack, S. (2010). The worldwide governance indicators: six, one, or none? The Journal of Development Studies, 46, 350-370.

Levitsky, S. and Way, L. A. (2002). Elections Without Democracy: The Rise of Competitive Authoritarianism. Journal of Democracy, 13, 51-65.

Levitsky, S. and Way, L. A. (2010). Competitive authoritarianism. Hybrid regimes after the Cold War. New York: Cambridge University Press. 
Lipset, S. 1994. The Social Requisites of Democracy Revisited. American Sociological Review, $59,1-22$.

McGrew, L., Frieson, K. and Chan, S. 2004. Good Governance from the Ground Up: Women's Roles in Post-Conflict Cambodia. Women Waging Peace Policy Commission.

Mkandawire, T. 2007. Good Governance: The Itinerary of an Idea. Development in Practice, $17,679-681$.

Mobarak, A. 2005. Democracy, Volatility and Development. The Review of Economics and Statistics, 87, 348-361.

Montinola, G. R. and Jackman, R. W. 2002. Sources of Corruption: A Cross-Country Study. British Journal of Political Science, 32, 147-170.

Morse, Y. 2012. The era of electoral authoritarianism. World Politics, 64, 161-198.

Munck, G. and Verkuilen, L. 2002. Conceptualizing and Measuring Democracy: Evaluating Alternative Indices. Comparative Political Studies, 35, 5-34.

Nanda, V. P. 2006. The "Good Governance" Concept Revisited. The Annals of the American Academy of Political and Social Science, 603, 269-283.

North, D. C. 1990. Institutions, Institutional Change and Economic Performance. Cambridge: Cambridge University Press.

Pritchett, L. and Kaufman, D. 1998. Civil Liberties, Democracy, and the Performance of Government Projects. Finance \& Development, 35, 26-29.

Quinn, R. and Dawson, L. 2011. Good Governance is a Choice: A Way to Re-create Your Board-the Right Way. Lanham: Rowman \& Littlefield Education.

Rock, M. T. 2009. Corruption and democracy. Journal of Development Studies, 45, 55-75.

Saha, S., Gounder, R. and Su J. J. 2009. The interaction effect of economic freedom and democracy on corruption: A panel cross-country analysis. Economics Letters, 105, 173-176. 
Saha, S. and Gounder, R. 2013. Corruption and Economic Development Nexus: Variations Across Income Levels in a Non-linear Framework. Economic Modelling, 31, 70-79.

Saha, S., Gounder, R., Campbell, N. and Su, J.J. 2014. 'Democracy and Corruption: A Complex Relationship', Crime Law and Social Change, 61, 287-308.

Shleifer, A. and Vishny, R. 1993. Corruption. Quarterly Journal of Economics, 108, 599-617.

Stockemer, D. 2009. Does Democracy Lead to Good Governance? The Question Applied to Africa and Latin America. Global Change, Peace \& Security, 21, 241-255.

Stockemer, D. 2014. Regime Type and Good Governance in Low and High Income States: What is the Empirical Link? Democratization, 21, 118-136.

Stoker, G. 1998. Governance as theory: five propositions. International Social Science Journal, $50,17-28$.

Sung, H. E. 2004. Democracy and political corruption: A cross-national comparison. Crime, Law and Social Change, 41, 179-193.

Transparency International 2016. Corruption in Afghanistan: What needs to change. Retrieved from: http://www.transparency.org/news/feature/corruption_in_afghanistan_what_needs_to_cha nge .

Treisman, D. 2000. The Causes of Corruption: A Cross-National Study. Journal of Public Economics, 76, 399-457.

Tronquist, O. 1999. Politics and Development. London: Sage.

Verardi, V. and Libois, F. 2012. XTSEMIPAR: Stata Module to Compute Semiparametric Fixed-Effects Estimator of Baltagi and Li. Statistical Software Components S457428, Boston College Department of Economics.

Wabuke, M. 2010. Eye on Africa: Perspectives of an African Native. Los Angeles: Coltan Books. 
Wooldridge, J. M. 2010. Econometric Analysis of Cross Section and Panel Data. $2^{\text {nd }}$ Edition, Cambridge Massachusetts: MIT Press.

World Bank 1989. Sub-Saharan Africa. From crisis to Sustainable Growth: A Long-Term Perspective Study. Washington D.C.: The World Bank.

World Bank 1992. Governance and Development. Washington D.C.: The World Bank.

World Bank 1994. Governance: The World Bank's Experience. Series: Development in Practice, Washington D.C.: The World Bank.

Zakaria, F. 2004. The Future of Freedom: Illiberal Democracy at Home and Abroad. New York: Norton. 
Table 1. PCA for WGIs ${ }^{a}$

\begin{tabular}{lllll} 
Component & Eigenvalue & Difference & Proportion & Cumulative \\
\hline Comp1 & 4.47169 & 4.12715 & 0.8943 & 0.8943 \\
Comp2 & 0.344538 & 0.241487 & 0.0689 & 0.9632 \\
Comp3 & 0.103051 & 0.058955 & 0.0206 & 0.9839 \\
Comp4 & 0.044096 & 0.007476 & 0.0088 & 0.9927 \\
Comp5 & 0.03662 &. & 0.0073 & 1 \\
\hline
\end{tabular}

Number of Observations $=1356$, Number of Components $=5$, Trace $=5$, Rho $=1$

aPCA generates five new variables which can explain the same information as the original five variables, which are Comp1 to Comp5. 
Table 2. Democracy-Governance Relationship, 1996-2012: PLS

\begin{tabular}{|c|c|c|c|c|}
\hline VARIABLES & $(1)$ & $(2)$ & (3) & $(4)$ \\
\hline DEMO & $\begin{array}{l}0.0232 \\
(0.0233)\end{array}$ & $\begin{array}{l}0.0190 \\
(0.0142)\end{array}$ & $\begin{array}{l}-0.424 * * * \\
(0.0664)\end{array}$ & $\begin{array}{l}-0.366^{* * *} \\
(0.0409)\end{array}$ \\
\hline $\mathrm{DEMO}^{2}$ & & & $\begin{array}{l}0.0442 * * * \\
(0.00623)\end{array}$ & $\begin{array}{l}0.0406 * * * \\
(0.00408)\end{array}$ \\
\hline $\operatorname{lnRGDP}$ & $\begin{array}{l}0.447 * * * \\
(0.0838)\end{array}$ & $\begin{array}{l}0.548 * * * \\
(0.0403)\end{array}$ & $\begin{array}{l}0.405 * * * \\
(0.0751)\end{array}$ & $\begin{array}{l}0.441 * * * \\
(0.0391)\end{array}$ \\
\hline $\ln \mathrm{POP}$ & $\begin{array}{l}-0.144 * * * \\
(0.0460)\end{array}$ & $\begin{array}{l}-0.0625 * * \\
(0.0243)\end{array}$ & $\begin{array}{l}-0.109 * * * \\
(0.0413)\end{array}$ & $\begin{array}{l}-0.0758 * * * \\
(0.0227)\end{array}$ \\
\hline SED & $\begin{array}{l}0.0121 * * * \\
(0.00358)\end{array}$ & $\begin{array}{l}0.0116^{* * * *} \\
(0.00202)\end{array}$ & $\begin{array}{l}0.0105 * * * \\
(0.00320)\end{array}$ & $\begin{array}{l}0.00972 * * * \\
(0.00189)\end{array}$ \\
\hline WOMENP (\%) & $\begin{array}{l}0.000643 \\
(0.00581)\end{array}$ & $\begin{array}{l}0.00819 * * \\
(0.00365)\end{array}$ & $\begin{array}{l}-0.00928^{*} \\
(0.00537)\end{array}$ & $\begin{array}{l}0.00375 \\
(0.00343)\end{array}$ \\
\hline NRA & $\begin{array}{l}-1.057 * * * \\
(0.233)\end{array}$ & $\begin{array}{l}-1.470 * * * \\
(0.127)\end{array}$ & $\begin{array}{l}-0.963 * * * \\
(0.209)\end{array}$ & $\begin{array}{l}-1.242 * * * \\
(0.120)\end{array}$ \\
\hline FEDERAL & $\begin{array}{l}-0.0412 \\
(0.143)\end{array}$ & $\begin{array}{l}0.128 \\
(0.0797)\end{array}$ & $\begin{array}{l}0.188 \\
(0.131)\end{array}$ & $\begin{array}{l}0.259 * * * \\
(0.0754)\end{array}$ \\
\hline CATHOLIC & $\begin{array}{l}-0.00747 * * * \\
(0.00232)\end{array}$ & $\begin{array}{l}-0.00672 * * * \\
(0.00110)\end{array}$ & $\begin{array}{l}-0.00558 * * * \\
(0.00209)\end{array}$ & $\begin{array}{l}-0.00491 * * * \\
(0.00104)\end{array}$ \\
\hline MUSLIM & $\begin{array}{l}-0.00621 * * * \\
(0.00230)\end{array}$ & $\begin{array}{l}-0.00108 \\
(0.00136)\end{array}$ & $\begin{array}{l}-0.00287 \\
(0.00211)\end{array}$ & $\begin{array}{l}0.00114 \\
(0.00129)\end{array}$ \\
\hline PROTESTANT & $\begin{array}{l}0.0132 * * * \\
(0.00460)\end{array}$ & $\begin{array}{l}0.0104 * * * \\
(0.00187)\end{array}$ & $\begin{array}{l}0.0173 * * * \\
(0.00414)\end{array}$ & $\begin{array}{l}0.0125 * * * \\
(0.00175)\end{array}$ \\
\hline $\mathrm{EF}$ & $\begin{array}{l}0.0702 * * * \\
(0.00855)\end{array}$ & $\begin{array}{l}0.0675 * * * \\
(0.00471)\end{array}$ & $\begin{array}{l}0.0628 * * * \\
(0.00770)\end{array}$ & $\begin{array}{l}0.0616 * * * \\
(0.00443)\end{array}$ \\
\hline GINI & $\begin{array}{l}-0.0373 * * * \\
(0.00693)\end{array}$ & & $\begin{array}{l}-0.0216 * * * \\
(0.00657)\end{array}$ & \\
\hline Constant & $\begin{array}{l}-4.246^{* * *} \\
(1.161)\end{array}$ & $\begin{array}{l}-7.949 * * * \\
(0.560)\end{array}$ & $\begin{array}{l}-4.131 * * * \\
(1.037)\end{array}$ & $\begin{array}{l}-6.206 * * * \\
(0.551)\end{array}$ \\
\hline $\begin{array}{l}\text { Observations } \\
\text { R-squared }\end{array}$ & $\begin{array}{l}206 \\
0.816\end{array}$ & $\begin{array}{l}659 \\
0.884\end{array}$ & $\begin{array}{l}206 \\
0.854\end{array}$ & $\begin{array}{l}659 \\
0.899\end{array}$ \\
\hline
\end{tabular}

Standard errors are in parentheses. ${ }^{* *},{ }^{* *}, *$ indicate significance level at the $1 \%, 5 \%$ and $10 \%$, respectively. Please note that due to the data limitations, the model which includes GINI variable shows less number of observations. 
Table 3. Non-linear Democracy-Governance Relationship, 1996-2012

\begin{tabular}{|c|c|c|}
\hline VARIABLES & $\begin{array}{l}5) \\
\text { FE }\end{array}$ & $\begin{array}{l}6) \\
\text { SGDP }\end{array}$ \\
\hline DEMO & $\begin{array}{l}-0.0700 \\
(0.0558)\end{array}$ & $\begin{array}{l}-0.239 * \\
(0.133)\end{array}$ \\
\hline $\mathrm{DEMO}^{2}$ & $\begin{array}{l}0.0114 * * \\
(0.00555)\end{array}$ & $\begin{array}{l}0.0289 * \\
(0.0158)\end{array}$ \\
\hline $\ln R G D P$ & $\begin{array}{l}0.403 * * * \\
(0.111)\end{array}$ & $\begin{array}{l}0.474 * * * \\
(0.146)\end{array}$ \\
\hline $\ln P O P$ & $\begin{array}{l}0.757 \\
(0.544)\end{array}$ & $\begin{array}{l}0.830 \\
(1.240)\end{array}$ \\
\hline SED & $\begin{array}{l}-0.000358 \\
(0.00147)\end{array}$ & $\begin{array}{l}0.00428 \\
(0.00429)\end{array}$ \\
\hline WOMENP (\%) & $\begin{array}{l}-0.00184 \\
(0.00387)\end{array}$ & $\begin{array}{l}0.00818 \\
(0.00926)\end{array}$ \\
\hline NRA & $\begin{array}{l}-0.152 \\
(0.227)\end{array}$ & $\begin{array}{l}-1.102 \\
(0.709)\end{array}$ \\
\hline $\mathrm{EF}$ & $\begin{array}{l}0.0202 * * * \\
(0.00478)\end{array}$ & $\begin{array}{l}0.0588 * * * \\
(0.0148)\end{array}$ \\
\hline Constant & $\begin{array}{l}-16.35 * \\
(9.433)\end{array}$ & $\begin{array}{l}-1.175 \\
(1.824)\end{array}$ \\
\hline $\begin{array}{l}\mathrm{P}-\mathrm{AR}(2) \\
\mathrm{P}-\text { Hansen }\end{array}$ & & $\begin{array}{l}0.675 \\
0.995\end{array}$ \\
\hline R-squared & 0.269 & \\
\hline Observations & 659 & 459 \\
\hline
\end{tabular}

Robust standard errors are in parentheses. ${ }^{* *},{ }^{* *},{ }^{*}$ indicate significance level at the $1 \%, 5 \%$ and $10 \%$, respectively. 
Table 4. Impact of Various Democracy Indicators on Governance, 1996-2012: Two-way-FE

\begin{tabular}{lllll}
\hline VARIABLES & $(7)$ & $(8)$ & $(9)$ & $(10)$ \\
\hline FREEDOM & & & & 0.0178 \\
& $0.0219^{*}$ & & $(0.0122)$ \\
CONTROL & $(0.0117)$ & & -0.000870 \\
& & 0.00505 & $(0.00570)$ \\
EQUALITY & $(0.00731)$ & & $0.0185^{* *}$ \\
Constant & & $0.0185^{* * *}$ & $(0.00788)$ \\
& 0.899 & & $(0.00614)$ & -1.946 \\
& $(17.22)$ & -4.044 & -10.03 & $(17.39)$ \\
Observations & 394 & $(18.15)$ & $(14.75)$ & 358 \\
Number of Countries & 38 & & & 34 \\
R-squared & 0.280 & 386 & 435 & 0.306 \\
\hline
\end{tabular}

Robust standard errors are in parentheses. $* * *, * *, *$ indicate significance level at the $1 \%, 5 \%$ and $10 \%$, respectively. All estimates include the control variables presented in equation (1).

Table 5. Impact of Democracy-Governance Relationship: Quantile Regressions Panel Data With FE

\begin{tabular}{llll}
\hline & $\mathrm{Q} 0.25$ & $\mathrm{Q} 0.50$ & $\mathrm{Q} 0.75$ \\
\hline VARIABLES & $(11)$ & $(12)$ & $(13)$ \\
\hline \multirow{2}{*}{ DEMO } & $-0.198^{* * *}$ & $-0.172^{* * *}$ & $-0.172^{* * *}$ \\
& $(0.055)$ & $(0.059)$ & $(0.066)$ \\
DEMO $^{2}$ & $0.0272^{* * *}$ & $0.0245^{* * *}$ & $0.0250^{* * *}$ \\
& $(0.006)$ & $(0.006)$ & $(0.007)$ \\
Constant & 1.937 & 1.948 & $2.153^{*}$ \\
& $(1.224)$ & $(1.225)$ & $(1.19)$ \\
Turning point & 4 & 4 & 3 \\
Observations & 206 & 206 & 206 \\
$F$-Statistic $(p$-value $)$ & $(0.000)$ & $(0.000)$ & $(0.000)$ \\
\hline
\end{tabular}

Bootstrap standard errors are in parentheses. $* * *, * *, *$ indicate significance level at the $1 \%, 5 \%$ and $10 \%$, respectively. Lower quantiles (e.g., Q 0.1) signify nations with lower quality of governance. All estimates include the control variables presented in equation (1). 
Figure 1. Scree Plot

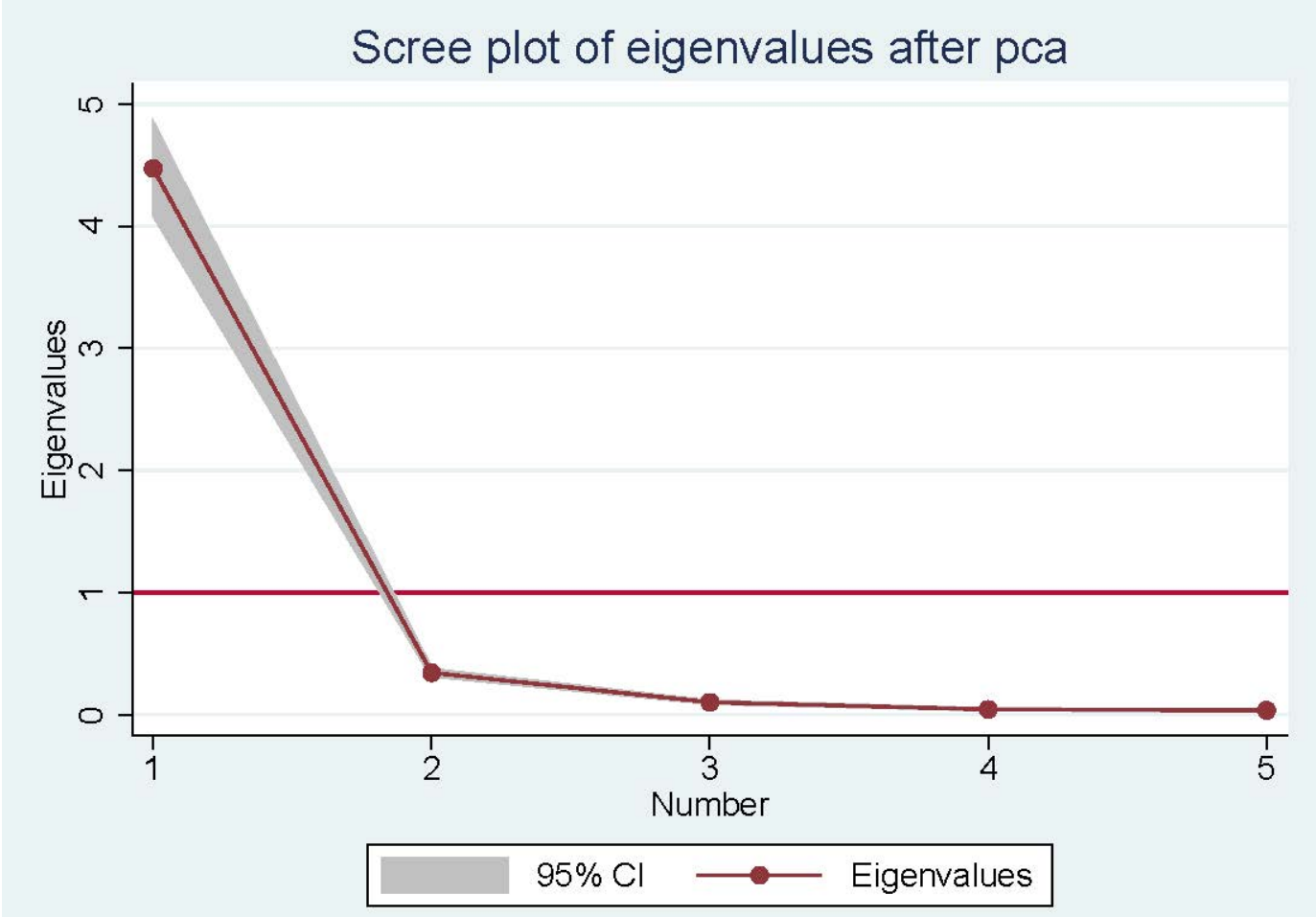

Figure 2. Governance and Democracy Relationship

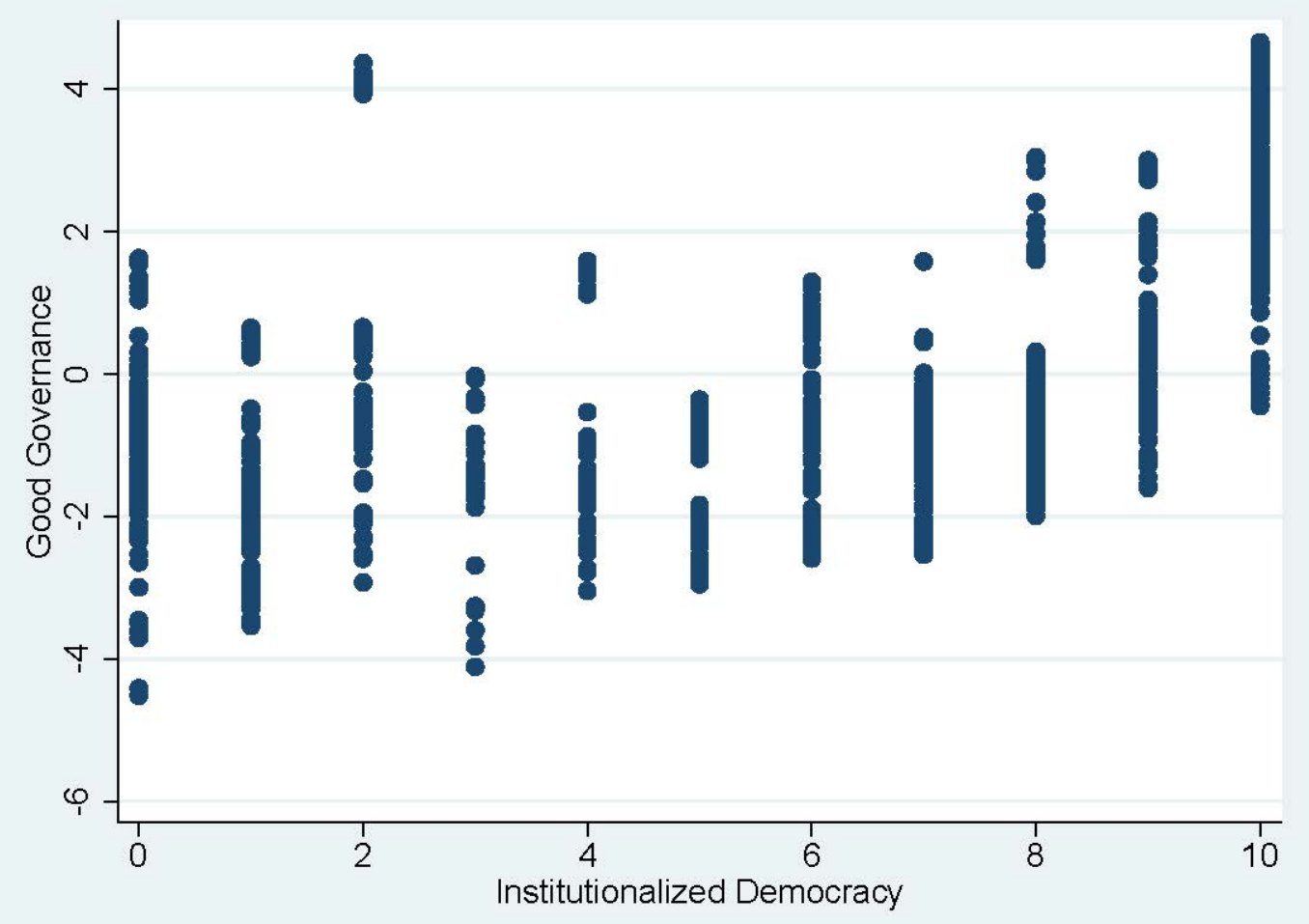


Figure 3. Non-linear Democracy-Governance Relationship

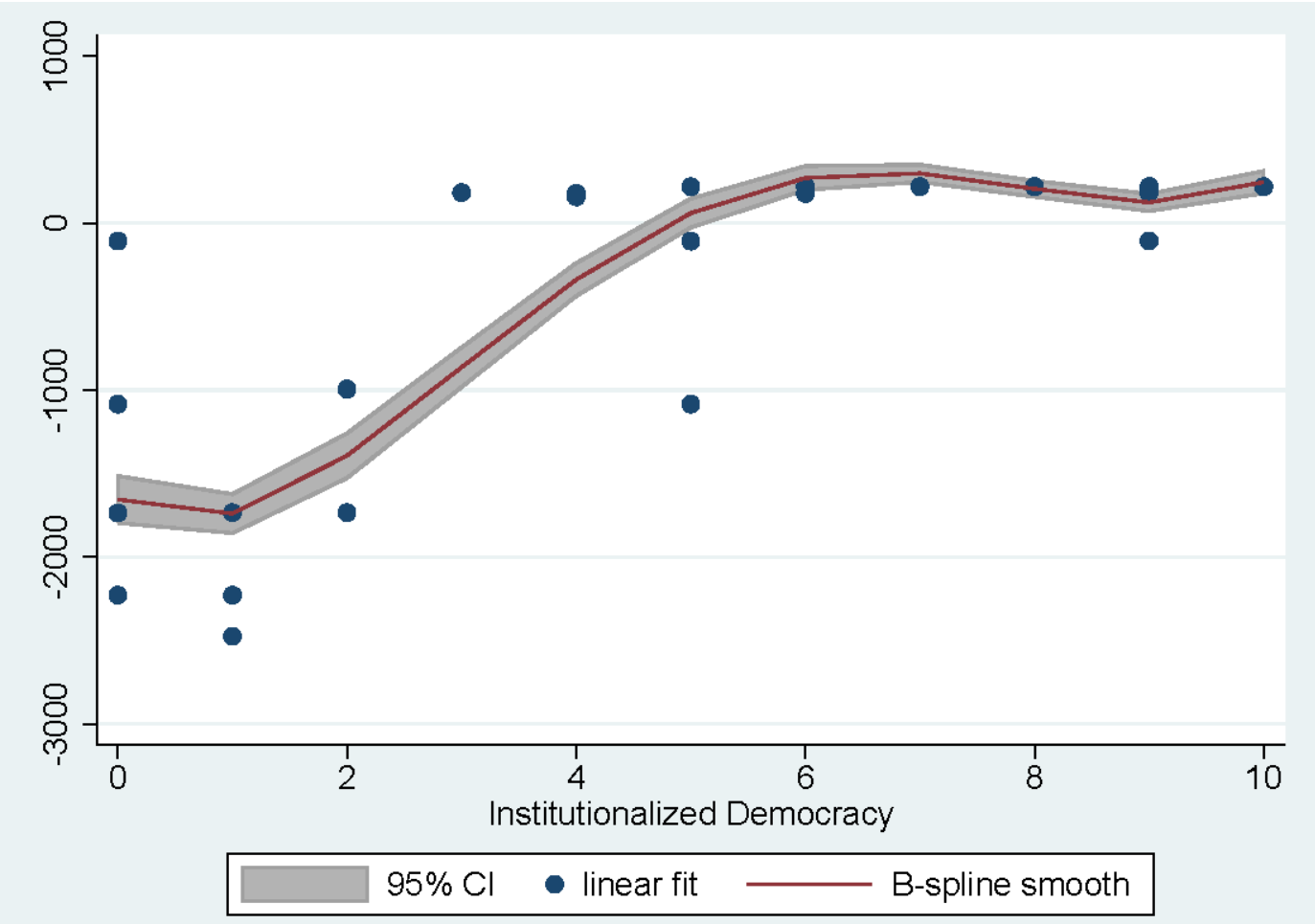


Appendix Table 1. Descriptive Statistics

\begin{tabular}{llllll}
\hline Variable & Mean & Std.Dev & Min & Max & Observations \\
\hline GG & $-5.47 \mathrm{e}-11$ & 2.291 & -5.812 & 4.992 & 1356 \\
DEMO & 1.640 & 18.46 & 0 & 10 & 2368 \\
lnRGDP & 7.657 & 1.668 & 4.171 & 11.46 & 2302 \\
lnPOP & 16.32 & 1.445 & 13.49 & 21.01 & 2356 \\
SED & 67.81 & 34.11 & 5.165 & 160.6 & 1740 \\
WOMENP(\%) & 15.37 & 10.53 & 0 & 56.30 & 1560 \\
NRA & 0.226 & 0.274 & 0 & 0.997 & 1976 \\
FEDERAL & 0.196 & 0.397 & 0 & 1 & 1608 \\
CATHOLIC & 32.82 & 36.01 & 0 & 96.90 & 2368 \\
PROTESTANT & 12.69 & 20.82 & 0 & 97.80 & 2368 \\
EF & 59.64 & 10.79 & 15.60 & 88.90 & 1679 \\
GINI & 45.25 & 9.463 & 24.32 & 74.33 & 518 \\
\hline
\end{tabular}

Appendix Table 2. Data Source

\begin{tabular}{|l|l|}
\hline Variable & Data Source \\
\hline GG & $\begin{array}{l}\text { Constructed using WGI available from: } \\
\text { http://databank.worldbank.org/data/home.aspx }\end{array}$ \\
\hline DEMO & Polity IV: http://www.systemicpeace.org/polity/polity4.htm \\
\hline $\begin{array}{l}\text { POP } \\
\text { WED }\end{array}$ & The World Bank Database: \\
GINI & $\underline{\text { http://databank.worldbank.org/data/home.aspx }}$ \\
\hline NRA & $\begin{array}{l}\text { Constructed by definition of Treisman (2000) using the World Bank } \\
\text { Database: http://databank.worldbank.org/data/home.aspx }\end{array}$ \\
\hline Federal State & The Quality of Government (QOG) Standard Dataset \\
\hline & Treisman (2000) \\
\hline & CIA The World Fact Book: \\
\hline
\end{tabular}

